\title{
DAMPAK KEBIJAKAN FISKAL DAN MONETER DALAM PEREKONOMIAN INDONESIA
}

\author{
Ada Tua Pardamean \\ Program Pasca Sarjana Universitas Negeri Medan \\ Jl. Williem Iskandar Ps. V Medan 20221, Telp. 061-6613365 \\ E-mail : rizky290@yahoo.co.id
}

\begin{abstract}
The trade-off between achieving price stability and economic growth, especially in the short term is the impact of a decision-making dilemma for the conduct of fiscal policy or monetary policy in the Indonesian economy. The problem is what lies behind this study and aimed to determine the impact of fiscal and monetary pol icies on the Indonesian economy. The data used are secondary data sourced from Bank Indonesia and BPS variables namely GDP, Government Expenditure, Tax Revenue, Export, Exchange Rate, Money Supply, Interest Rates for time series from 2000 to 2012. Data analysis was performed using Two Stage Least Squares (TSLS) estimation with multiple linear regression models using Eviews 5.0 program assistance. The results of this study it can be concluded that the simultaneous equation model on IS to variable Interest Rate and a significant negative effect on GDP of Indonesia, while the Government Expenditure variable (G0), Export (X0) and Tax Revenue (Tx) and Exchange Rate (ER) effect positively and significantly to Indonesia's GDP, while the equation for the LM model of the Money Supply variables significantly and negatively related to Indonesia's GDP increased at a rate statistically $\alpha=$ $10 \%$ and for variable interest rate is not significantly to Indonesia's GDP.
\end{abstract}

Keywords:GDP, Government expenditure, Tax Revenue, Exports, Dollar Exchange Rate, Money Supply, Interest Rates

\section{PENDAHULUAN}

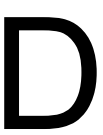

alam perekonomian terbuka dan sistem devisa bebas, kebijakan moneter yang longgar dapat berdampak pada kenaikan harga/inflasi dan mengurangi daya saing produk dalam negeri dan pada akhirnya akan menurunkan devisa. Sementara itu, kebijakan moneter ketat akan memberi dampak sebaliknya, terutama dalam rangka meredam kenaikan harga atau inflasi yang berlebihan, sehingga tekanan terhadap neraca pembayaran berkurang karena produk dalam negeri kembali dapat bersaing, meskipun dengan

QE Journal |Vol.02 - No.03 - 36 
kebijakan ini akan berdampak pula pada menurunnya pertumbuhan ekonomi, karena jumlah uang yang beredar dikurangi, yang berarti permintaan juga berkurang.

Krisis ekonomi memberi pelajaran kepada bangsa Indonesia bahwa beberapa indikator-indikator ekonomi makro yang memuaskan belum menjadi jaminan bahwa kondisi ekonomi Indonesia memang kuat. Untuk mencapai tingkat pertumbuhan dan kegiatan ekonomi seperti pada masa sebelum krisis ekonomi pada akhir dekade 1990-an pilihan kebijakan ekonomi untuk menstabilisasi perekonomian adalah kebijakan fiskal dan moneter. Pada saat ekonomi dirasakan berjalan terlalu lambat dari yang seharusnya yang ditandai dengan rendahnya pertumbuhan dan tingginya tingkat pengangguran, maka dengan kebijakan fiskal dan moneter yang tepat diharapkan dapat mendorong perekonomian tumbuh lebih cepat dan pengangguran dapat ditekan. Sedangkan pada saat perekonomian dianggap terlalu laju yang ditandai dengan pertumbuhan yang tinggi dan tingkat inflasi yang juga tinggi, kebijakan fiskal dan moneter diharapkan dapat menekan dan mengarahkan perekonomian agar terhindar dari dampak negatif.

Kebijakan fiskal dan kebijakan moneter merupakan bagian integral dari kebijakan makroekonomi yang memiliki target yang harus dicapai baik dalam jangka pendek dan jangka panjang. Sudah lama terjadi perdebatan antara kebijakan fiskal dan moneter. Di satu sisi, kebijakan moneter diarahkan pada pencapaian target menjaga stabilitas tingkat harga. Sementara itu di sisi lain kebijakan fiskal ditetapkan untuk mencapai pertumbuhan ekonomi. Dari sini nampaknya muncul trade-off antara pencapaian stabilitas harga dan pertumbuhan ekonomi terutama dalam jangka pendek. Kebijakan defisit fiskal yang tinggi dapat menyebabkan kenaikan tingkat inflasi, sebaliknya perekonomian dengan tingkat inflasi yang tinggi juga memberikan dampak negatif bagi pertumbuhan ekonomi. Perkembangan perekonomian yang semakin dinamis dan terintegrasi dengan perekonomian dunia memberikan implikasi penting bagi para pelaku ekonomi terutama dalam pengambilan kebijakan makroekonomi. Pengelolaan kebijakan fiskal dan moneter melalui koordinasi yang baik akan memberikan sinyal positif bagi pasar dan menjaga stabilitas makroekonomi.

Dalam mempelajari dan menganalisis fenomena ekonomi dibutuhkan model atau teori. Fungsi model atau teori adalah untuk membantu dalam menjelaskan fenomena - fenomena ekonomi. Model ekonomi makro yang sering digunakan untuk menganalisis bagaimana kebijakan fiskal dan moneter bekerja dalam perekonomian terbuka adalah Model Mundell - Fleming. Nanga $(2005 ; 205)$ menyatakan bahwa: Model Mund ell-Fleming sesuai namanya diperkenalkan atau dikembangkan oleh Robert Mundell dan Marcus Fleming tahun 1962, dan merupakan versi model IS-LM untuk perekonomian terbuka (open economy). 
Kontribusi utama kedua ahli tersebut adalah karena mereka memasukkan pergerakan modal antar negara (international capital movement) kedalam model makroekonomi formal yang didasarkan atas kerangka IS-LM dari Keynesian. Tulisan-tulisan kedua ahli ekonomi ini memiliki sejumlah implikasi penting menyangkut keefektifan kebijakan fiskal dan moneter (effectiveness of fiscal and monetary policy) dalam menciptakan keseimbangan internal maupun eksternal (internal balance and external balance).

Senada dengan hal tersebut, Mankiw (2006:338)meny ebutkan bahw abaik model ISLM maupun model Mundell-Fleming menekankan interaksi di antara pasar barang dan pasar uang. Selain itu, kedua model tersebut mengasumsikan bahwa tingkat harga adalah tetap (fixed) dan menunjukkan faktor apa yang menyebabkan fluktuasi jangka pendek di dalam pendapatan agregat (atau pergeseran di dalam permintaan agregat). Perbedaan yang utama di antara kedua model tersebut adalah terletak pada asumsi mereka menyangkut perekonomian, dimana dalam model IS-LM perekonomian diasumsikan sebagai perekonomian tertutup (closed economy), sebaliknya dalam model Mundell-Fleming di asumsikan sebagai perekonomian terbuka (open economy). Model Mundell-Fleming mengasumsikan perekonomian yang ditelaah sebagai perekonomian kecilyang terbuka dengan mobilitas modal sempurna (small open economy with perfect capital mobility). Kebijakan makroekonomi dalam konteks perekonomian terbuka (open economy), khususnya dalam kaitan dengan upaya mengoreksi ketidakseimbangan dalam neraca penbayaran, sering kali di pilih dalam dua jenis atau macam yaitu expenditure-changing policies dan expenditure-switching policies. Adapun yang dimaksud dengan kebijakan "expenditure-changing" adalah kebijakan yang mencakup kebijakan fiskal dan moneter, yang ditujukan untuk mempengaruhi tingkat permintaan agregat (agregate demand atau AD) atau absorpsi dalam negeri (domestic absorption atau DA) y ang terdiri atas pengeluaran konsumsi, pengeluaran investasi, dan pengeluaran pemerintah di dalam perekonomian.Sedangkan yang dimaksud dengan "expenditure-switching" adalah kebijakan yang mencakup devaluasi dan revaluasi, yang ditujukan untuk mengalihkan (to switch) pengeluaran dari suatu negeri dari barang luar negeri ke barang dalam negeri atau sebaliknya.

Alat pemerintah untuk mempengaruhi kegiatan ekonomi adalah dengan menggunakan kebijakan fiskal dan moneter. Kebijakan fiskal merupakan kebijakan yang dilakukan oleh pemerintah untuk mempengaruhi perekonomian dengan menggunakan instrumen variabel pajak (tax), transfer pemerintah atau dengan pengeluaran pemerintah (Reksoprayitno, 2000:89) sedangkan Kebijakan moneter merupakan kebijakan pemerintah yang dilakukan otoritas moneter (Bank Sentral) untuk mempengaruhi perekonomian dengan cara penambahan atau pengurangan

QE Journal | Vol.02 - No.03 - 38 
jumlah uang beredar yang biasa disebut dengan penawaran uang Menurut Reksoprayitno (2000:90).

Dalam model IS-LM, instrumen kebijakan fiskal yang biasa digunakan adalah pengeluaran pemerintah dan pajak.Sedangkan instrument kebijakan moneter yang biasa digunakan adalah jumlah uang beredar (JUB)domestik. (Sugiyanto, 2004). Mankiw (2007) mengemukakan bahwa Model Mundell-Flemingmembuat satu asumsi penting dan ekstrem, yakni model ini mengasumsikan bahwa model yangsedang di pelajari adalah perekonomian kecil terbuka dengan aliran modal sempurna.

Dari sudut ekonomi makro maka kebijakan fiskal dapat dibedakan menjadi dua yaituKebijakan Fiskal Ekspansif adalah suatu kebijakan ekonomi dalam rangka mengarahkan kondisi perekonomian untuk menjadi lebih baik dengan jalan mengubah penerimaan dan pengeluaran pemerintah, pada saat munculnya kontraksional gap yaitu suatu kondisi dimana potensial $\left(\mathrm{Y}_{\mathrm{f}}\right)$ lebih tinggi dibandingkan dengan Aktual $\left(\mathrm{Y}_{1}\right)$ sedangkanKebijakan Fiskal Kontraktif adalah kebijakan pemerintah dengan cara menurunkan belanja negara dan menaikkan tingkat pajak. Kebijakan ini bertujuan untuk menurunkan daya beli masyarakat dan mengatasi inflasi. kebijakan pemerintah untuk membuat pemasukannya lebih besar daripada pengeluarannya. Baiknya politik anggaran surplus dilaksanakan ketika perekonomian pada kondisi yang ekspansi yang mulai memanas (overheating) untuk menurunkan tekanan permintaan pada saat munculnya ekpansionary gap yaitu suatu kondisi dimana potensial $\left(\mathrm{Y}_{\mathrm{f}}\right)$ lebih kecil dibandingkan dengan Aktual ( $\left.\mathrm{Y}_{1}\right)$.

Alat/instrumen kebijakan moneter yang umum dilakukan menurutpendapat Mishkin (Nopirin, 2000:135) terdiri dari: (1) Operasi Pasar Terbuka(Open Market Operation), (2) Fasilitas Diskonto (Discount Rate), (3)Rasio Cadangan Wajib (Reserve Requirement Ratio)dan.(4) Himbauan Moral (Moral Persuasion).

Beberapa penelitian telah dilakukan berkaitan dengan Model Mundell Fleming dan perekonomian kecil terbuka, seperti yang dilakukan Konuki (2000:19) menganalisis dampak jangka pendek kebijakan fiskal dan moneter terhadap permintaan agregat dengan menggunakan pendekatan model IS-LM-BP dan metode analisis Structural ECM. Data yang diteliti adalah data perekonomian Negara Swiss yang mengadopsi system nilai tukar fleksibel. Dari penelitian tersebut menunjukkan perbandingan Model tradisional Mundell-Fleming dan Model Dornsbusch. Setelah kebijakan moneter (fiskal) diperlonggar, mata uang domestik terdepresiasi (terapresiasi) untuk periode waktu yang substantial dan permintaan agregat mengamalami ekspansi (kontraksi) kemudian secara gradual kembali ke arah alur aslinya. Dampak rangsangan dari kebijakan moneter 
ekspansif adalah pada depresiasi nilai tukar domestik, kemudian akan meningkatkan ekspor dan permintaan agregat naik. Dampak dari kebijakan fiskal ekspansif didominasikan dengan dampak negatif pada apresiasi nilai tukar, kemudian impor turun ekspor naik dan permintaan agregat turun.

Madjid (2007:117) menggunakan variasi model IS - LM untuk menganalisis efektivitas antara Kebijakan Fiskal dan Kebijakan Moneter (Studi Kasus Indonesia Tahun 1970-2005, sebagai negara perkonomian terbuka dengan sistem kurs mengambang dengan menggunakan metodologi Error Correction Model EngleGranger (ECM-EG). Hasil penelitian menunjukkan bahwa multiplier kebijakan fiskal sebesar 0,6 dan multiplier kebijakan moneter sebesar 2,6 sedangkan rata-rata keseimbangan perekonomian Indonesia terjadi pada Pendapatan Nasional sebesar 895.292,83 (miliar) dan tingkat bunga sebesar 11,29 persen. Berdasarkan penelitian yang telah dilaksanakan dapat disimpulkan bahwa kebijakan moneter akan lebih efektif dalam mempengaruhi Produk Domestik Bruto dibandingkan dengan kebijakan fiskal.

Santoso, dkk (2009:126) dalam penelitiannya yang berjudul Dampak Kebijakan Fiskal dan Moneter terhadap perekonomian Indonesia; Aplikasi Model MundellFleming menyatakan pada persamaan IS, PDB yang mencerminkan dari sisi pengeluaran agregat dipengaruhi secara positif dan signifikan variabel konsumsi, investasi, permintaan uang (jumlah uang beredar), perubahan cadangan devisa dan PDB periode sebelumnya. Sementara variabel inflasi berpengaruh negatif dan signifikan terhadap PDB. Pengaruh negatif variabel inflasi tersebut menunjukkan berlakunya Keynes Effect dalam perekonomian Indonesia. Variabel tingkat bunga juga berpengaruh negatif, namun tidak signifikan terhadap PDB. Dalam persamaan LM, PDB di pengaruhi secara positif dan signifikan oleh tingkat bunga, permintaan uang (jumlah uang beradar) dan PDB periode sebelumnya. Secara umum, koefisien dalam persamaan LM mempunyai besaran yang inelastis, sehingga sesuai dengan pandangan golongan Monetaris terhadap kurva LM Kebijakan moneter dalam bentuk pengaturan jumlah uang beredar (permintaan uang) terbukti lebih signifikan dalam meningkatkan PDB dari sisi permintaan, dimana terdapat hubungan positif dan signifikan pada tingkat kepercayaan 1 persen antara variabel permintaan uang $\left(\mathrm{M}_{2}\right)$ dan PDB dari sisi permintaan. Kebijakan fiskal melalui variabel pengeluaran pemerintah juga mempunyai dampak positif dan signifikan terhadap PDB, namun dengan tingkat kepercayaan yang lebih besar dari pada kebijakan moneter, yakni sebesar 10 persen. Sehingga temuan tersebut mendukung bahwa model Mundell-Fleming, di mana kebijakan moneter memberikan pengaruh lebih besar dan efektif dalam meningkatkan PDB, sementara kebijakan fiskal memberikan pengaruh yang lebih kecil dalam meningkatkan PDB dari pada kebijakan moneter. Kebijakan fiskal kurang 
berpengaruh terhadap peningkatan PDB, sebagai akibat dari adanya crowding out effect y ang menegasikan seluruh dampak kebijakan fiskal.

Penelitian lain yang dilakukan oleh Atmaja (2001:28) tentang Free Floating Exchange Rate System dan penerapannya pada kebijakan ekonomi di negara yang berperekonomian kecil dan terbuka dengan menggunakan asumsi mobilitas modal yang sempurnamodelMundell-Fleming terbukti mampu menjelaskan bahwa penerapan sistem nilai tukar mengambang bebas akan mengakibatkan dampak yang tidak sama antara negara yang berperekonomian besar, atau negara maju, dengan negara yang berperekonomian kecil. Oleh karenanya diperlukan suatu kehati-hatian dalam mengaplikasikan sistem nilai tukar mata uang tersebut.

\section{METODE PENELITIAN}

Penelitian ini menggunakan data sekunder yang meliputi Produk Domestik bruto (PDB), pengeluaran pemerintah, penerimaan pajak, ekspor, nilai tukar, permintaan uang, dan tingkat bunga runtun waktu (time series) periode tahun 2000 sampai dengan tahun 2012. Metode analisis yang digunakan berupa penelitian deskriptif dan penelitian kuantitatif.

Penelitian deskriptif yaitu menyajikan penggambaran atau potret suatu kondisi dan situasi yang sebenarnya dari suatu permasalahan yang terjadi berdasarkan fakta yang diperoleh pada suatu waktu tertentu. Sedangkan penelitian kuantitatif adalah penelitian dengan sasaran penelitian yang luas dengan penekanan analisis pada data-data numerik dan digunakan untuk menguji suatu teori dengan metode statistika. Model estimasi yang dibentuk akan dianalisis dengan menggunakan paket olah data Eviews 5,0 dengan model simultan, yang akan diselesaikan dengan pendekatan Two Stage Least Square (TSLS).

Dalam penelitian ini terdapat dua jenis variabel, yakni variabel endogen dan variabelpredetermined atau variabel bebas dalam persamaan simultan di mana nilainya ditentukan di luarmodel (Gujarati, 2003).Variabel predetermined di bagi menjadi dua kategori, yakni eksogen (eksogenmurni ataupun eksogen lag), dan endogen lag Variabel endogen dalam penelitian ini yaitu:

\section{Persamaan Model IS :}

$\mathrm{K}=$ (banyaknya predetermined variable dalam model) ada 5 variabel yaitu variabel $\mathrm{G}_{0}, \mathrm{X}_{0}, \mathrm{Tx}$, ER dan $\mathrm{MS}_{0}$.

$\mathrm{K}=$ (banyaknya predetermined va riabledalam persamaan) ada 4 variabel yaitu variabel $\mathrm{G}_{0}, \mathrm{X}_{0}$, Tx dan ER.

$\mathrm{M}=$ (banyaknya endogeneus variable dalam model) ada 2 variabel yaitu variabel Y dan variabel $r$. 
$\mathrm{m}$ = (banyaknya endogeneus variable dalam persamaan) ada 1 variabel yaitu variabel Y.

\section{Persamaan Model LM:}

$\mathrm{K}=$ (banyaknya predetermined variable dalam model) ada 5 variabel yaitu variabel $\mathrm{G}_{0}, \mathrm{X}_{0}, \mathrm{Tx}$, ER dan MS.

$\mathrm{K}=$ (banyaknya predetermined variabledalam persamaan) ada 1 variabel yaitu variabel MSo.

$\mathrm{M}$ = (banyaknya endogeneus variable dalam model) ada 2 variabel yaitu variabel variabel $Y$ dan variabel $r$.

$\mathrm{m}$ = (banyaknya endogeneus variable dalam persamaan) ada 1 variabel yaitu variabel $r$.

Variabel-variabel tersebut dispesifikasikan ke dalam dua model persamaan sesuaidengan hubungan teoritisnya, yang akan diselesaikan dengan pendekatan TSLS, formulasi model penelitian ini sebagai berikut:

\section{Persa maan Model IS}

$$
\begin{aligned}
& \mathrm{Y}=\mathrm{C}+\mathrm{I}+\mathrm{G}+\mathrm{X}-\mathrm{M} \\
& Y=\frac{\alpha_{0}-\beta_{0}-\delta_{0}}{\delta_{1}+\beta_{1}}-\frac{\alpha_{1}}{\delta_{1}+\beta_{1}} r+\frac{1}{\delta_{1}+\beta_{1}} G_{0}-\frac{1}{\delta_{1}+\beta_{1}} T_{x}+\frac{1}{\delta_{1}+\beta_{1}} X_{0}-\frac{\beta_{2}}{\delta_{1} \beta_{1}} E R \\
& Y=\pi_{11}-\pi_{12} r+\pi_{13} G_{0}-\pi_{14} T_{x}+\pi_{15} X_{0}-\pi_{16} E R
\end{aligned}
$$

IS $(Y)=f\left(r, G, T x, X_{0}, E R\right)$

Reduce Form :

(IS) $Y=\beta_{0}-\beta_{1} \mathbf{r}+\beta_{2} \mathbf{G}_{0}-\beta_{3} \mathbf{T} \mathbf{x}+\beta_{4} \mathbf{X}_{0}-\beta_{5} \mathbf{E} \mathbf{R}$

Keterangan:

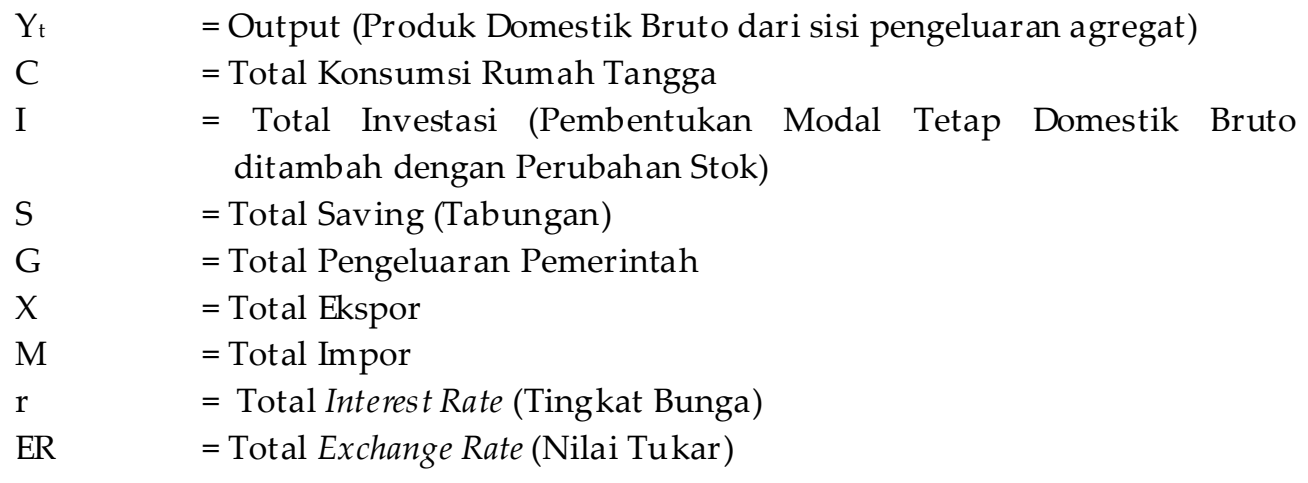


$\alpha_{0}-\alpha_{8} \quad=$ Koefisien Variabel

\section{Persamaan Model LM}

$$
\begin{aligned}
& \mathrm{MD}=\mathrm{MS} \\
& \mathrm{MD}=\mathrm{f}\left(\mathrm{Y}_{1}, \mathrm{r}\right) \\
& \mathrm{MD}=\alpha_{0}+\alpha_{1} \mathrm{Y}-\alpha_{2} \mathrm{r} \\
& \mathrm{LM}=\mathrm{Y}=\pi_{21}+\pi_{22} r+\pi_{23} M S_{0}
\end{aligned}
$$

Reduce Form :

$$
\mathrm{Y}=\pi_{0}+\pi_{1} \mathrm{r}+\pi_{3} \mathrm{MS}_{0}
$$

Keterangan:

$$
\begin{array}{ll}
\mathrm{Y} & =\text { Output (Produk Domestik Bruto dari Sisi Pengeluaran Agregat) } \\
\mathrm{r} & =\text { Total Interest Rate (Tingkat Bunga) } \\
\mathrm{MS}_{0} & =\text { Penaw aran Uang (Jumlah Uang Beredar) }
\end{array}
$$

Pengolahan data sekunder dan penerapan ketiga metode di atasakan menggunakan program (software) statisitik Eviews versi 5.0. Dengan melakukan uji asumsi klasik dan signifikan, yang terdiri dari : uji serempak (F-test), koefisien determinasi $\left(\mathrm{R}^{2}\right)$, uji parsial (t-test), uji multikolinearitas, uji autokorelasi, dan uji normalitas.

Berdasarkan hasil identifikasi persamaan simultan tersebut diketahui bahwa kedua persamaan adalah over identified, sehingga model estimasi yang digunakan adalah Two Stage Least Squares (TSLS). Metode TSLS ini lebih tepat digunakan untuk analisis simultan, mengingat dalam analisis ini semua variabel diperhitungkan sebagai suatu system secara menyeluruh.

Prosedur TSLS adalah sebagai berikut : (Gujarati, 2006:167):

1. Tahap I : estimasi persamaan tereduksi dengan OLS untuk menghasilkan nilai estimasi variabel endogen.

2. Tahap II : estimasi model persamaan simultan dengan OLS dengan menggunakan nilai estimasi variabel endogen sebagai variabel eksogen.

3. Hasil estimasi pada tahap II merupakan hasil estimasi TSLS.

\section{HASIL DAN PEMBAHASAN}

Persamaan Model IS pada variabel pengeluaran pemerintah (G0) berpengaruh positip dan signifikan terhadap peningkatan PDB Indonesia secara statistik pada tingkat $\alpha=10$ persen.Variabel total ekspor $\left(X_{0}\right)$ berpengaruh positip dan suku bunga (r) berpengaruh negatif tapi tidak signifikan secara statistik pada tingkat $\alpha=$ 10 persen. Sedangkan variabel pajak (Tx) berpengaruh negatif dan signifikan

QE Journal | Vol.02 - No.03 - 43 
secara statistik pada tingkat $\alpha=10$ persen, variabel nilai tukar (ER) berpengaruh negatif namun tidak signifikan secara statistik pada tingkat $\alpha=10$ persen. Arah pengaruh seluruh variabel terhadap terhadap PDB menunjukkan sesuai dengan ekspektasi teori.

Untuk model LM pada Variabel jumlah uang beredar berpengaruh positif dan signifikan pada tingkat $\alpha=10$ persen, sedangkan untuk variabel suku bunga berpengaruh positif dan signifikan terhadap peningkatan PDB Indonesia secara statistik pada tingkat $\alpha=10$ persen.

\section{Hasil Uji Asumsi Ekonometrika}

\section{Uji Normalitas}

Tabel 2. Deskriptif Statistik

\begin{tabular}{lcc}
\hline & RESID01 & RESID02 \\
\hline Mean & $-1.56 \mathrm{E}-09$ & $1.37 \mathrm{E}-10$ \\
Median & -7414.175 & 7403.100 \\
Maximum & 107390.7 & 369948.4 \\
Minimum & -105204.3 & -342785.2 \\
Std. Dev. & 66722.97 & 212950.5 \\
Skewness & 0.097637 & 0.174823 \\
Kurtosis & 2.002407 & 2.283898 \\
Jarque-Bera & 0.473607 & 0.291067 \\
Probability & 0.789146 & 0.864561 \\
Sum & $-1.72 \mathrm{E}-08$ & $1.40 \mathrm{E}-09$ \\
Sum Sq. Dev. & $4.45 \mathrm{E}+10$ & $4.53 \mathrm{E}+11$ \\
Observations & 11 & 11 \\
\hline
\end{tabular}

Sumber : Hasil Olah deng an Eviews 5.0

Tabel 2 menunjukkan bahwa residual $01 \mathrm{JB}=0.473607$ dan pada Residual 02 nilai $\mathrm{JB}=0.291067$ dan lebih besar pada $\alpha=10$ persen, artinya residual dari $Y$ (IS) dan $\mathrm{Y}$ (LM) terdistribusi secara normal atau memenuhi asumsi normalitas.

\section{Uji Autokorelasi}

Untuk uji autokorelasi didapat dari hasil uji estimasi Durbin-Watson Test (Uji DW). Hasil estimasi menghasilkan nilai statistik DW sebesar 1,22 pada persamaan $Y$ (IS), dan sebesar 0,31 pada persamaan Y (LM). Angka ini terletak di sebelah kanan tengah gambar berikut, daerah tersebut menunjukkan daerah tidak dapat disimpulkan (no decision).

Pada persamaan $Y$ (IS), DW tabel pada taraf signifikan $\alpha=0,05$, dengan jumlah sampel $n=22$ serta jumlah variable bebas $\mathrm{k}=5$ adalah nilai $\mathrm{dL}=1,026$ dan $\mathrm{dU}=$

QE Journal |Vol.02 - No.03 - 44 
1,669. Nilai hitung $\mathrm{DW}=1,22$, berada di sebelah dU yang berarti berada pada daerah tidak dapat disimpulkan.

\section{Uji Multikolinearitas}

Uji moultikolinearitas menggunakan VIF dan Tolerence. Untuk menghitung VIF dan Tolerence terlebih dahulu ditentukan matriks korelasi variabel pengeluaran pemerintah $\left(\mathrm{G}_{0}\right)$, ekspor $\left(\mathrm{X}_{0}\right)$, pajak $(\mathrm{Tx})$, nilai tukar $(\mathrm{ER})$, suku bunga $(\mathrm{r})$ dan jumlah uang beredar $\left(\mathrm{MS}_{0}\right)$ yang ditunjukkan pada tabel 4.3.

Tabel 3. Matriks Korelasi Variabel Bebas

\begin{tabular}{ccrrrrr}
\hline & $\mathrm{ER}$ & \multicolumn{1}{c}{$\mathrm{G}_{0}$} & \multicolumn{1}{c}{$\mathrm{MS}_{0}$} & \multicolumn{1}{c}{$\mathrm{R}$} & $\mathrm{Tx}$ & \multicolumn{1}{c}{$\mathrm{X}_{0}$} \\
\hline ER & 1.000000 & -0.027130 & -0.090171 & -0.400943 & -0.352664 & 0.050626 \\
$\mathrm{G}_{0}$ & -0.027130 & 1.000000 & -0.748668 & 0.120203 & 0.539902 & 0.919015 \\
$\mathrm{MS}_{0}$ & -0.090171 & -0.748668 & 1.000000 & 0.196854 & -0.622679 & -0.662019 \\
$\mathrm{R}$ & -0.400943 & 0.120203 & 0.196854 & 1.000000 & -0.286238 & 0.169742 \\
Tx & -0.352664 & 0.539902 & -0.622679 & -0.286238 & 1.000000 & 0.294674 \\
$\mathrm{X}_{0}$ & 0.050626 & 0.919015 & -0.662019 & 0.169742 & 0.294674 & 1.000000 \\
\hline
\end{tabular}

Sumber : Hasil Olah deng an Eviews 5.0

Nilai VIF yang semakin besar menunjukkan masalah multikolinearitas yang semakin serius. Kaidah yang digunakan adalah jika VIF lebih besar dari 10 dan $R_{j}^{2}$ lebih besar dari 0,90 maka variabel tersebut memiliki kolinearitas yang tinggi.

Tabel 4. Nilai VIF dari Korelasi Variable Bebas

\begin{tabular}{|c|c|c|c|c|c|c|}
\hline & ER & $\mathrm{G}_{0}$ & $\mathrm{MS}_{0}$ & $\mathrm{R}$ & $\mathrm{Tx}$ & $X_{0}$ \\
\hline ER & 1 & & & & & \\
\hline $\mathrm{G}_{0}$ & 0.99926 & 1 & & & & \\
\hline $\mathrm{MS}_{0}$ & 0.99187 & 0.43950 & 1 & & & \\
\hline $\mathrm{R}$ & 0.83924 & 0.98555 & 0.96125 & 1 & & \\
\hline $\mathrm{Tx}$ & 0.87563 & 0.70851 & 0.61227 & 0.91807 & 1 & \\
\hline $\mathrm{X}_{0}$ & 0.99744 & 0.15541 & 0.56173 & 0.97119 & 0.91317 & 1 \\
\hline
\end{tabular}

Sumber : Hasil Olah deng an Eviews 5.0

Dari nilai VIF dari korelasi variabel-variabel bebas pada tabel 4.4 tidak terdapat variabel yang memiliki nilai VIF yang lebih besar dari 10, jadi tidak terjadikolinieritasganda(multicollinearity).

Dilihat dari tabel 4. maka, variabel $\mathrm{G}_{0}, \mathrm{X}_{0}$ dan $\mathrm{MS}_{0}$ yang memiliki nilai Tolerence yang tinggi, yaitu 0,99 sementara variabel lainnya masih dibaw ah nilai TOL yaitu 0,90 . Meskipun nilai TOL untuk variabel tersebut tinggi, namun nilai tersebut masih dibaw ah 1.

QE Journal |Vol.02 - No.03 - 45 


\section{Analisis Hasil Estimasi Model Penelitian}

Hasil estimasi model penelitian dengan menggunakan metode Two Stage Least Square (2SLS) adalah sebagai berikut :

PDB $(\mathrm{IS})=11.889 .696-27.323 \log (\mathrm{r})+1.538 .718 \log (\mathrm{G})-260.309 \log (\mathrm{Tx})+22.737$

$$
\log (X)-220.758 \log (E R)
$$

$\operatorname{PDB}(\mathrm{LM})=2.754 .245+311.324 \log (\mathrm{r})+715.275 \log (\mathrm{JUB})$

Dari hasil estimasi diketahui bahwa pengeluaran pemerintah berpengaruh positif terhadap PDB Indonesia. Dimana variabel pengeluaran pemerintah memiliki nilai probabilitysebesar $0,0009<0,10$.Untuk variabel total ekspor memiliki nilai probability sebesar 0,9113 >0,10, variabel pajak memiliki nilai probability sebesar 0,0540<0,10. Variabel nilai tukar memiliki nilai probability sebesar $0,7167>0,10$. Sedangkan variabel suku bunga memiliki nilai probability sebesar 0,6564 >0,10.

Hasil estimasi tersebut menunjukkan bahwa variabel Pengeluaran pemerintah, ekspor, berpengaruh positip terhadap peningkatan PDB Indonesia, sedangkan variabel pajak, nilai tukar dan suku bunga berpengaruh negatif terhadap PDB Indonesia, namun variabel jumlah uang beredar dan suku bungan berpengaruh positif atau dapat meningkatkan PDB Indonesia.

Secara detail dapat dinyataakan sebagai berikut:

a. Setiap kenaikan pengeluaran pemerintah sebesar 1 persen, maka akan meningkatkan PDB sebesar Rp. 1.538.718 miliar.

b. Setiap kenaikan Ekspor sebesar 1 persen, maka akan meningkatkan PDB sebesar Rp. 22.737 miliar.

c. Setiap kenaikan Pajak sebesar 1 persen, maka akan menurunkan PDB sebesar Rp. 260.309 miliar.

d. Setiap kenaikan nilai tukar sebesar 1 persen, maka akan menurunkan PDB sebesar Rp. 220.758 miliar.

e. Setiap kenaikan Suku bunga sebesar 1 persen, maka akan menurunkan PDB sebesar Rp. 27.323 miliar.

dan :

a. Setiap kenaikan jumlah uang beredar sebesar 1 persen, maka akan meningkatkan PDB sebesar Rp. 715.275 miliar.

b. Setiap kenaikan Suku bunga sebesar 1 persen, maka akan meningkatkan PDB sebesar Rp. 311.324 miliar.

Pembahasan Uji Kriteria Statistik

QE Journal |Vol.02 - No.03 - 46 
Uji kriteria statistik dilakukan berdasarkan prinsip-prinsip statistik, yang meliputi pengujian kebermaknaan regresi secara parsial dan pengujian ketepatan letak taksiran garis regresi.

\section{a. Uji Regresi Secara Parsial (Uji t)}

Pengujian koefisien regresi secara parsial bertujuan untuk mengetahui pengaruh dari masing-masing variabel bebas (independent variable) terhadap variabel terikat (dependent variable). Pengujian ini dilakukan dengan menggunakan uji t (t-test).

Kebermaknaan secara parsial dengan menggunakan uji $t$ (t-test) dengan tingkat signifkansi 10 persen ( $\alpha=10$ persen), serta derajat kebebasan ( $\delta \mathrm{f})$ adalah n-k-1 $=52-5-1=46$, maka diperoleh nilai kritis $\mathrm{t}$-tabel sebesar 1,684 atau dengan menggunakan p-value. Selanjutnya dengan membandingkan nilai t-hitung dan tlabel dapat diny atakan bahwa :

Variabel pengeluaran pemerintah positif dan signifikan terhadap pertumbuhan ekonomi (IS) karena nilai probability sebesar 0,0009 signifikan lebih kecil dari $\alpha=10$ persen. Variabel ekspor tidak berpengaruh terhadap pertumbuhan ekonomi (IS) karena nilai probability sebesar 0,9113 lebih besar dari $\alpha=10$ persen. Variabel pajak berpengaruh negatif dan signifikan terhadap pertumbuhan ekonomi (IS) karena nilai probability sebesar 0,0540 signifikan lebih kecil dari $\alpha=10$ persen. Variabel nilai tukar tidak berpengaruh terhadap pertumbuhan ekonomi (IS) karena nilai probability sebesar 0,7167 lebih besar dari $\alpha=10$ persen. Variabel suku bunga tidak berpengaruh terhadap pertumbuhan ekonomi (IS) karena nilai probability sebesar 0,6564 lebih besar dari $\alpha=10$ persen.

Variabel suku bunga berpengaruh signifikan terhadap pertumbuhan ekonomi (LM) karena nilai probability sebesar 0,0701 signifikan lebih kecil dari $\alpha=10$ persen. Variabel jumlah uang beredar berpengaruh negatif dan signifikan terhadap pertumbuhan ekonomi (LM) karena memiliki nilai probability sebesar 0,0037 signifikan lebih kecil dari $\alpha=10$ persen.

\section{Uji Ketepatan Letak Taksiran Garis Regresi (Goodness of Fit)}

Uji ketepatan letak taksiran garis regresi ini, dapat ditunjukkan oleh besarnya nilai koefisien determinasi $\left(R^{2}\right)$, yang besarnya antara nol dan satu $\left(0<R^{2}<1\right)$. Semakin tinggi nilai $R^{2}$ (mendekati 1 ), berarti estimasi model regresi yang dihasilkan semakin mendekati keadaan yang sebenarnya (goodness of fit) atau menunjukkan tepatnya letak taksiran garis regresi yang diperoleh.

Dari hasil estimasi model diperoleh nilai $\mathrm{R}^{2}$ untuk model pertumbuhan ekonomi (IS) sebesar 0.972514. Ini berarti, bahwa sebesar 97,25 persen proporsi variabelvariabel bebas yang digunakan mampu menjelaskan variasi variabel terikat dalam model tersebut, sedangkan sisanya yang hanya sebesar 2,75 persen dijelaskan oleh 
variabel lain yang tidak digunakan dalam penelitian ini. Sedangkan untuk model pertumbuhan ekonomi (LM) diperoleh nilai $\mathrm{R}^{2}$ sebesar 0.720029. Ini berarti, bahwa sebesar 72,00 persen proporsi variabel-variabel bebas yang digunakan mampu menjelaskan variasi variabel terikat dalam model tersebut, sedangkan sisanya yang hanya sebesar 28,00 persen dijelaskan oleh variabel lain yang tidak digunakan dalam penelitian ini. Nilai $\mathrm{R}^{2}$ ini memperlihatkan estimasi model yang dihasilkan dari penelitian ini baik memperlihatkan keadaan yang sebenarnya (goodness of fit) atau kuat untuk dipercaya.

\section{KESIMPULAN DAN SARAN}

Berdasarkan hasil penelitian, maka dapat diambil kesimpulan sebagai berikut :

1. Pada Persamaan Model IS untukvariabel pengeluaran pemerintah $\left(\mathrm{G}_{0}\right)$, total ekspor $\left(\mathrm{X}_{0}\right)$, berpengaruh positip terhadap peningkatan PDB Indonesia, sedangkan Variabel penerimaan pajak (Tx), nilai tukar (ER), suku bunga (r) berpengaruh negatif. dan signifikan secara statistik pada tingkat $\alpha=10$ persen, variabel berpengaruh negatif, namun tidak signifikan secara statistik pada tingkat $\alpha=10$ persen. Arah pengaruh seluruh variabel terhadap terhadap PDB menunjukkan sesuai dengan ekspektasi teori.

Secara detail dapat dinyataakan sebagai berikut:

a. Setiap kenaikan pengeluaran pemerintah sebesar 1 persen, maka akan meningkatkan PDB sebesar Rp. 1.538.718 miliar.

b. Setiap kenaikan Ekspor sebesar 1 persen, maka akan meningkatkan PDB sebesar Rp. 22.737 miliar.

c. Setiap kenaikan Pajak sebesar 1 persen, maka akan menurunkan PDB sebesar Rp. 260.309 miliar.

d. Setiap kenaikan nilai tukar sebesar 1 persen, maka akan menurunkan PDB sebesar Rp. 220.758 miliar.

e. Setiap kenaikan Suku bunga sebesar 1 persen, maka akan menurunkan PDB sebesar Rp. 27.323 miliar.

2. Pada persamaan Model LM untukvariabel jumlah uang beredar dan suku bunga berpengaruh positif dan signifikan terhadap peningkatan PDB Indonesia secara statistik pada tingkat $\alpha=10$ persen atau dapat dinyatkan bahwa:

a. Setiap kenaikan jumlah uang beredar sebesar 1 persen, maka akan meningkatkan PDB sebesar Rp. 715.275 miliar.

QE Journal |Vol.02 - No.03 - 48 
b. Setiap kenaikan Suku bunga sebesar 1 persen, maka akan meningkatkan PDB sebesar Rp. 311.324 miliar.

Saran

1. Diharapkan kepada pemerintah agar konsisten menjaga tingkat bunga yang stabil dan mendorong kebijakan yang dapat meningkatkan sektor riil sehingga perekonomian dapat terus tumbuh dan stabilitas tetap terjaga.

2. Diharapkan agar pemerintah menciptakan iklim yang baik bagi investor yang ingin menanamkan investasinya dengan memberikan kemudahan proses dan pelay anan perizinan.

3. Bagi peneliti selanjutnya diharapkan bisa meneliti faktor-faktor lain yangmempengaruhi penerimaan yang berasal dari pajak, tidak hanya dari segi ekonomi tetapi juga bisa dilihat dari faktor sosialbudaya,politik dan hukum, atau dapat juga dilihat dari segi kondisi negarapengimpor sehingga dapat diketahui dengan jelas faktor-faktor apa saja yang, mempengaruhi penerimaan negara dari pajak.

\section{DAFTAR PUSTAKA}

Aliman dan A Budi Purnomo. 2001. Kausalitas antara Ekspor dan Pertumbuhan Ekonomi. Jurnal Ekonomi dan bisnis Indonesia, Vol. 16, No.2.

Anwar, Khairil. 2011. Pengaruh Intermediasi Keuangan Dan Jumlah Uang Beredar Terhadap Pertumbuhan Ekonomi Indonesia. Jurnal E-Mabis Vol. 12 No. 1.

Asri, Nur.2005, Pengaruh Pengeluaran Pemerintah Terhadap Pertumbuhan Ekonomi Dan Distribusi Pendapatan (Kajian Antar Propinsi di Indonesia Periode 19942003). Tesis. Program Pascasarjana Universitas Andalas.

Atmadja, Adwin Surya. 2001, Free Floating Exchange Rate System dan Penerapannya Pada kebijaksanaan Ekonomi di Negara Yang Berperekonomian Kecil dan Terbuka, Jurnal Akuntansi dan Keuangan, Vol 3 , No. 1.

Badan Pusat Statistik. 2000-2012, "Produk Domestik Bruto", www.bi.go.id

Bank Indonesia. 2013, Statistik Ekonomi dan Keuangan Indonesia (SEKI), Berbagai edisi penerbitan.

----------, www bi.go.id. Jakarta: Bank Indonesia

Engen E.M and Skinner J. 1992, Fiscal Policy and Economic Growth, Cambridge,NB ER Working Paper Series No. 4223

Gujarati, Damodar. 2006, Ekonometrika Dasar, Alih bahasa Sumarno Zain, Jakarta. Erlangga.

QE Journal |Vol.02 - No.03 - 49 
Gulo, Angadrowa. 2008,Analisis Pengaruh Aspek Fiskal Dan Moneter Terhadap Pertumbuhan Ekonomi Indonesia, Tesis, Sekolah PascasarjanaUniversitas Sumatera Utara.

Guritno, Mangkoesoebroto. 1993, Ekonomi publik, Ed. 3; Cet.1, BPFE-Yogyakarta.

Jamzani Sodik. 2007. Pengeluaran Pemerintah dan Pertumbuhan Ekonomi Regional : Studi Kasus Data Panel di Indonesia. Jurnal Ekonomi Pembangunan (JEP) Vol. 12 No. 1.

Jung, W.S dan J. Marshall. 1985. "Export, Growth And Causality In Developing Countries". Journal of Development Economics, 18 : 1-12. North-Holland

Konuki, Tetsuya. 2000. The effect of monetary policy on agregat demand in small open economy: An aplication of the structural error correction model. IMF Working Paper. Fiscal Affair Department

Ma'ruf, Ahmad dan Wihastuti, Latri. 2006, Pertumbuhan Ekonomi Indonesia, Determinan Dan Prospeknya, Jurnal Ekonomi dan Studi Pembangunan, Vol 9 , No. 1

Madjid,Noor Cholis. 2007, Analisis efektivitas antara kebijakan fiskal dan kebijakan moneter dengan pendekatan model IS - LM (studi kasus indonesia tahun 1970 2005). Tesis. Program Pascasarjana Universitas Diponegoro Semarang.

Mankiw, Gregory N. 2006, Macroekonomi, Edisi 6, Alih bahasa Fitria Liza dan Imam Nurmawan, Penerbit Erlangga, Jakarta.

Metwally, M.M. 1995, Teori dan Model Ekonomi Islam, PT. Bangkit Daya Insana, Edisi Pertama, Jakarta

Kuncoro, Mudrajad. 2004. Otonomi dan Pembangunan Daerah:Reformasi, Perencanaan, Strategi, dan Peluang. Yogyakarta:Erlangga

Nanga, Muana. 2005. Makro Ekonomi, Edisi Perdana : PT Raja Grafindo Persada. Jakarta.

Nopirin, 2000. Pengantar Ilmu Ekonomi, Makro dan Mikro, Edisi Pertama, BPFE, Yogyakarta.

Nuary, Sanny. 2005. Analisis Jumlah Uang Beredar, Suku Bunga dan Pertumbuhan Ekonomi di Indonesia Tahun 1970-2002, Tesis, Sekolah pascasarjana.Universitas Sumatera Utara.

Putra, Muhammad Angga Pratama. 2009, Analisa Keterkaitan Antara Ekspor dan Pertumbuhan Ekonomi Indonesia Periode Tahun 1960-2009. Skripsi Universitas Sumatera Utara.

QE Journal |Vol.02 - No.03 - 50 
Rahardja, Prathama dan Manurung, Mandala. 2008, Teori Ekonomi Makro Edisi Keempat. Jakarta: Lembaga Penerbit Fakultas Ekonomi Indonesia.

Raman, Abdur. 2009, Analisis Efektivitas Kebijakan Fiskal Dan Moneter Terhadap Produk Domestik Bruto Indonesia, Tesis, Sekolah PascasarjanaUniversitas Sumatera Utara

Reksoprayitno Soediyono. 2000, Ekonomi Makro, Edisi Millennium, BPFE UGM Yogjakarta

Samuelson, Paul A. dan Nordhaus, Wiliam, 1996, IlmuMakroeconomi, Alih Bahasa Haris Munanandar, Dkk, Erlangga, Jakarta.

Santoso, Teguh, Maruto Umar basuki. 2009, Dampak kebijakan fiscal dan Moneter dalam Perekonomian Indonesia; Aplikasi Model Mundell-Fleming, Jurnal Organisasi dan Manajemen, Volume 5,nomor 2.

Soediyono R. 1981, Ekonomi Makro: Pengantar Analisis PendapatanNasional, Penerbit Liberty, Yogyakarta.

Sukirno, Sadono. 2004. Makro Ekonomi Modren, Perkembangan Pemikiran dari Klasik hingga Keynesian Baru, PT. Raja Grafindo, Jakarta.

Suparmoko, M. 1997, Keuangan Negara Dalam Teori dan Praktek, Cet.VII, BPFE, Yogyakarta.

Yulianti, Sri Handaru dan Prasetyo, Handoyo. 1998. Dasar-dasar Manajemen Keuangan Internasional. Andi. Yogyakarta. Edisi Pertama

QE Journal |Vol.02 - No.03 - 51 